\title{
Are Covid-19 Pandemic Physical Activity Levels Affect Balance, Gait, Cognitive Functions and Fear of Covid-19 of Older Adults?
}

\author{
Covid-19 Pandemisinde Fiziksel Aktivite Düzeyleri, Yaşlilarm Denge, Yürüme, Bilişsel Fonksiyonlar ve Covid-19 \\ Korkusu Düzeylerini Etkiler Mi?
}

\section{${ }^{1}$ Elvan Ozcan Gulsen, ${ }^{2}$ Cagri Gulsen, ${ }^{3}$ Fatih Soke, ${ }^{1}$ Melahat Sayan, ${ }^{4}$ Oznur Tunca Yilmaz}

${ }^{1}$ Department of Physical Therapy and Rehabilitation, Faculty of Health Sciences, Yüksek İhtisas University,

Ankara, Turkey.

${ }^{2}$ Gazi University, Faculty of Health Sciences, Department of Physiotherapy and Rehabilitation, Ankara, Turkey

${ }^{3}$ Gülhane Faculty of Physiotherapy and Rehabilitation, University of Health Sciences, Ankara, Turkey.

${ }^{4}$ Faculty of Physical Therapy and Rehabilitation, Hacettepe University, Ankara, Turkey.

\section{Abstract}

The aim of this study is to compare the balance, gait, cognitive functions and fear of Covid-19 (FoC-19) in older adults according to physical activity levels (PALs) and investigate the relationship between PALs and balance, gait, cognitive functions and FoC-19 of older adults in times of Covid-19 pandemic. 40 healthy older adults were divided into two groups as low and high PALs groups according to their median score on the Physical Activity Scale for the Elderly. Outcome measures included the Berg Balance Scale, Timed Up and Go Test, 10 Meter Walk Test, Trail Making Test and the FoC-19 Scale. Older adults who have low PALs in times of Covid-19 pandemic have worse outcomes in terms of balance, gait and FoC-19. There is no difference in terms of cognitive functions. Also, there is no relationship between PALs and other parameters except FoC-19 in older adults who have low PALs and there is no relationship between PALs and other parameters in older adults who have high PALs. Low PALs in times of Covid-19 pandemic negatively affected balance, gait and FoC-19 of older adults. It is also found that PALs of older adults related with the FoC-19.

Keywords: Physical activity level; balance; gait; cognitive functions; fear of Covid-19; older adults

\section{Özet}

Bu çalışmanın amacı Covid-19 pandemisi sırasında yaşlıların denge, yürüme, bilişsel fonksiyonlar ve Covid-19 korkularını fizikse aktivite düzeylerine göre karșılastırmak ve fiziksel aktivite düzeyi ile denge, yürüme, bilissel fonksiyonlar ve Covid-19 korkusu arasındaki ilişkiyi incelemektir. Çalışmaya katılan 40 sağlıklı yaşlı, Yaşlılar İçin Fiziksel Aktivite Ölçeği medyan puanlarına göre düşük fizksel aktivite düzeyi grubu ve yüksek fiziksel aktivite düzeyi grubu olarak iki gruba ayrılmıştır. Değerlendirme ölçeği olarak Berg Denge Ölçeği, Süreli Kalk ve Yürü Testi, 10 Metre Yürüme Testi, İz Sürme Testi ve Covid-19 Korku Ölçeği kullanılmıștır. Covid-19 pandemisi sırasında daha düşük fiziksel aktivite düzeyine sahip olan yaşlıların denge, yürüme ve Covid-19 korkusu bakımından daha kötü sonuçlara sahip olduğu gözlendi. Bilișsel fonkiyonlar açısından ise gruplar arası farklılık gözlenmedi. Ayrıca, düşük fiziksel aktivite düzeyine sahip yaşlllarda, fiziksel aktivite düzeyleri ile Covid-19 korkusu dışındaki diğer parametrelerle bir ilişki olduğu gözlenirken, yüksek fiziksel aktivite düzeyine sahip yaşlılarda fiziksel aktivite düzeyleri ile bütün parametreler arasında bir ilișki olduğu gözlemlenmiștir. Covid-19 pandemisi sırasında düșük aktivite düzeyi yaşlıların denge, yürüme ve Covid-19 korkularını olumsuz yönde etkilemektedir. Ayrıca, yaşlıların fiziksel aktivite düzeylerinin Covid-19 korkusu ile ilişkili olduğu bulunmuștur.

Anahtar Kelimeler: Fiziksel aktivite düzeyi; denge; yürüme; bilişsel fonksiyonlar; Covid-19 korkusu, yaşllar 


\section{Introduction}

Since December 2019, numerous cases of dangerous viral pneumonia have been reported in connection with a seafood market in Wuhan, Hubei Province, China (1). Due to the rapid spread of this infectious virus around the globe, the World Health Organization (WHO) named this disease 2019 Coronavirus Disease (Covid-19) and declared it as a global pandemic in March 2020 (2). Consequently, government authorities decided to take extreme countermeasures for the purpose of preventing the spread of the virus. The first coronavirus case in Turkey was reported on March 10, 2020 and the first coronavirus related death was reported on March 17, 2020 (3). As a result of this, similar countermeasures have also been taken in Turkey. It has been reported that the older adults and individuals with chronic diseases constitute the high-risk group in coronavirus risk maps. Several countermeasures have been taken for older people since they are at high risk and establish a significant population group in Turkey. As of March 21, 2020, a lockdown was issued for people aged 65 and over (4).

Physical activity can be defined as body movements that require energy expenditure (5). Physical activity helps to protect physical and mental health, reduces depressive symptoms and preserves cognitive level, so it improves the quality of life (6). Balance deficits are associated with physical inactivity in older people (7). Also, there is evidence that older adults with higher physical activity levels (PALs) have better walking parameters than those with lower PALs (8). In addition to these results, it is reported that cognitive functions are higher in older adults with a high level of physical activity compared to sedentary ones (9). It is also stated that there is a relationship between PALs and fear of Covid-19 in healthy younger adults (10).

Social isolation due to pandemic countermeasures appears to affect older adults bio-psycho-socially. Physical and mental conditions of older adults who are less socially active may deteriorate $(11,12)$. There is evidence about that the pandemic countermeasures have reduced the PALs of older adults (13). The World Health Organization recommends at least 150 minutes of moderate-intensity or 75 minutes of vigorous-intensity or an equivalent combination of moderate and vigorous intensity aerobic physical activity for a week for individuals aged 65 and over (14). It is recommended that older adults who spend more time at home due to the restrictions in times of the pandemic should increase their PALs and exercise regularly in order to protect their physical, mental and cognitive functions (15). However, PALs and differences in physical, cognitive and mental performances between physically active and inactive older adults in times of Covid-19 pandemic remain unclear. Therefore, the aim of this study is to compare the balance, gait, cognitive functions and fear of Covid-19 in older adults according to PALs and investigate the relationship between PALs and balance, gait, cognitive functions and fear of Covid-19 of older adults in times of Covid-19 pandemic.

\section{Materials and Methods}

\section{Study design}

This cross-sectional, observational study was performed at the Physiotherapy and Rehabilitation Department, Yuksek Ihtisas University. The study took place between December 2020 and February 2021. Yuksek Ihtisas University Clinical Research Ethics Committee approved the study, with approval number 2020/16/03. All participants signed an informed consent form according to the Declaration of Helsinki.

\section{Participants}

A convenience sample of 40 healthy older adults have participated in this study. Participants were recruited through poster advertising from community. Inclusion criteria were being 65 years old or more, the ability to walk independently and being cognitively unimpaired (Mini mental state examination score 24 or above). Exclusion criteria were having an orthopedic, neuromuscular or rheumatologic disease that may affect assessments, any 
hearing or speech disorder and having an institutionalized care. The median score of the Physical Activity Scale for the Elderly (PASE) was calculated as 53,36 and this value was used as cut-off score to divide the participants into two groups as the low physical activity level (Low-PAL) group and high physical activity level (High-PAL) group, considering the median value of nonparametric variables can be used to create groups (16).

\section{Outcome measures and procedures}

Assessments were completed in a single session. Three minutes of resting periods were given between each assessment to minimize fatigue effect. The order of assessments was randomized. The assessments were applied in a quiet environment. Demographic data of the participants (e.g., age, sex, body mass index, educational level) were recorded.

\section{Assessment of Physical Activity Level}

The Turkish version of the PASE was used to assess the physical activity level of older adults. The PASE consists of 12 self-reported components about leisure-time (5 components), household (6 components), and occupational ( 1 component) activities over the past seven days. The scoring manual provides weights for each component and an equation to compute the total score (17).

\section{Assessment of Balance}

The Berg Balance Scale (BBS) was used for assessing the balance. The BBS is a widely used assessment tool for functional balance. The BBS has 14 items, each of which is scored from 0 to 4 according the level of balance impairment. Higher scores of BBS indicate better balance performance (18).

\section{Assessment of Gait}

Gait was assessed with Timed Up and Go Test (TUG) and 10 Meter Walk Test (10MWT). Completing the TUG requires participants to stand up from a chair with armrests, walk 3 meters, turn around, walk back to the chair and sit down (19). The time taken to complete the test is recorded using a stopwatch. The 10MWT requires walking at a comfortable pace over a distance of 10 meters (20). The time taken to complete the test was recorded.

\section{Assessment of Cognitive Functions}

The Trail Making Test Part A (TMT-A) and Part B (TMT-B) were used to assess the cognitive functions. In the TMT-A, participants are required to combine the numerated circles with drawing direct lines with an ascending order. In the TMT-A, participants are required to combine the circles consisting of both letters and numbers by drawing direct lines in ascending order as one number and one letter. The TMT measures psychomotor speed, sequencing ability, attention, visual scanning, mental flexibility, motor speed, working memory, coordination and executive function (21). Time to complete each part was assessed and the TMT-A, the TMT-B and the TMT-B minus the TMT-A (TMT- $\Delta$ ) times were recorded.

\section{Assessment of the Fear of Covid-19}

The Turkish version of the Fear of Covid-19 Scale was used to assess the fear related to Covid-19. It consists of 7 items and possible scores ranging from 7 to 35 , with higher scores indicating higher fear (22).

\section{Statistical analysis}

Data analysis was performed by using IBM SPSS Statistics 21.0 (IBM Corp. Armonk, NY). Descriptive statistics were presented as median (interquartile range) and number (percentage). $\chi 2$ tests were used for the comparison of categorical data. Comparisons of continuous and ordinal variables between the low physical activity level group and high physical activity level group were performed by using the MannWhitney $U$ test. The relationships between the PALs and the other parameters were investigated with using the Spearman correlation analysis. Statistical significance was considered at $\mathrm{p}<0.05$ for all analyses. 


\section{Results}

40 community-dwelling older adults were included in this study. The participants were divided into two groups as the Low-PAL group (12 men, 8 women; median age, 69 years) and the High-PAL group (11 men, 9 women; median age, 68 years) according to median PASE score. The characteristics of the participants are shown in Table 1. The two groups were similar by means of age, sex, body mass index and educational level $(\mathrm{p}>0,05)($ Table 1).

Table 1. Participants' characteristics

\begin{tabular}{|c|c|c|c|}
\hline Demographics & Low-PAL $(n=20)$ & High-PAL $(n=20)$ & $\mathbf{p}$ \\
\hline & Median (IQR 25-75) & Median (IQR 25-75) & \\
\hline & $\mathrm{n}(\%)$ & $\mathrm{n}(\%)$ & \\
\hline Age (years) & $69(67.5-77)$ & $68(66-69)$ & $0.061^{\mathrm{a}}$ \\
\hline BMI $\left(\mathrm{kg} / \mathrm{m}^{2}\right)$ & $28.46(25.96-29.79)$ & $28.26(26.85-29.23)$ & $0.882^{\mathrm{a}}$ \\
\hline \multicolumn{4}{|l|}{ Gender } \\
\hline Female & $12(60)$ & $11(55)$ & \multirow[t]{2}{*}{$0.749^{b}$} \\
\hline Male & $8(40)$ & $9(45)$ & \\
\hline Years of Education & $8(4-10)$ & $8(4-12)$ & $0.909^{\mathrm{a}}$ \\
\hline PASE Scores & $26.35(14.52-34.06)$ & $66.48(61.38-85.20)$ & $<0.001^{\mathrm{a}}$ \\
\hline
\end{tabular}

Data were given median $\left(25^{\text {th }}-75^{\text {th }} I Q R\right)$ or $n(\%)$, IQR $=$ Interquartile Range, BMI=Body Mass Index, PASE $=$ The Physical Activity Scale for the Elderly, ${ }^{a}$ Mann-Whitney U Test, ${ }^{b}$ Chi-square Test.

There are statistically significant differences between the Low-PAL group and the HighPAL group in terms of BBS scores, TUG scores, 10MWT scores and the Fear of Covid19 Scale scores. However, there is no statistically significant difference between the Low-PAL group and the High-PAL group in terms of TMT-A, TMT-B and TMT- $\Delta$ scores $(\mathrm{p}>0,05)($ Table 2).

Table 2. Comparison of evaluated parameters between Low-PAL and High-PAL groups

\begin{tabular}{llll}
\hline Variable & Low-PAL $(\mathbf{n}=\mathbf{2 0})$ & High-PAL $(\mathbf{n}=\mathbf{2 0})$ & $\mathbf{p}$ \\
\hline & Median (IQR 25-75) & Median (IQR 25-75) & \\
\hline BBS (0-56) & $53(50.5-55.5)$ & $56(53.5-56)$ & $0.030^{*}$ \\
\hline TUG (seconds) & $9.40(8.21-11.39)$ & $8.08(7.13-8.95)$ & $0.010^{*}$ \\
\hline 10MWT (seconds) & $7.74(6.79-9.79)$ & $6.91(6.05-7.48)$ & $0.026^{*}$ \\
\hline TMT-A (seconds) & $70.69(52.41-103.84)$ & $62.21(45.14-101.18)$ & 0.484 \\
\hline TMT-B (seconds) & $127.39(103.99-179.13)$ & $125.85(84.05-165.60)$ & 0.646 \\
\hline TMT- $\Delta$ (seconds) & $54.79(40.23-68.28)$ & $53.16(37.02-68.80)$ & 0.829 \\
\hline Fear of Covid-19 Scale (7-35) & $18(17-19)$ & $12(10.5-16)$ & $0.001 *$ \\
\hline
\end{tabular}

Data were given median $\left(25^{\text {th }}-75^{\text {th }} I Q R\right), I Q R=$ Interquartile Range, BBS=Berg Balance Scale, TUG=Timed Up and Go Test, $10 M W T=10$ Meter Walk Test, TMT = Trail Making Test, ${ }^{a}$ Mann-Whitney U Test, ${ }^{*} p<0.05$.

There are no statistically significant relationships between PALs and BBS scores, TUG scores, 10MWT scores, TMT-A, TMT$\mathrm{B}$ and TMT- $\Delta$ scores of the Low-PAL group $(p>0,05)$. However, there is moderate relationship between PALs and the Fear of Covid-19 Scale score of Low-PAL group ( $\mathrm{r}=-$ 0.650, $\mathrm{p}=0.002$ ). Also, there are no 
statistically significant relationships between PALs and other parameters of the High-PAL group $(p>0,05)$. Additionally, there are weak relationships between PALs and BBS $\operatorname{scores}(\mathrm{r}=0.344, \mathrm{p}=0.030), \quad \mathrm{TUG} \operatorname{scores}(\mathrm{r}=-$
0.417, $\mathrm{p}=0.007), 10 \mathrm{MWT}$ scores $(\mathrm{r}=-0.376$, $\mathrm{p}=0.017)$ and moderate relationship between PALs and the Fear of Covid-19 Scale score $(\mathrm{r}=-0.683, \mathrm{p}<0.001)$ of the total sample (Table $3)$.

Table 3. The relationship of the evaluated parameters and PASE Scores in Low-PAL and High-PAL groups and whole sample.

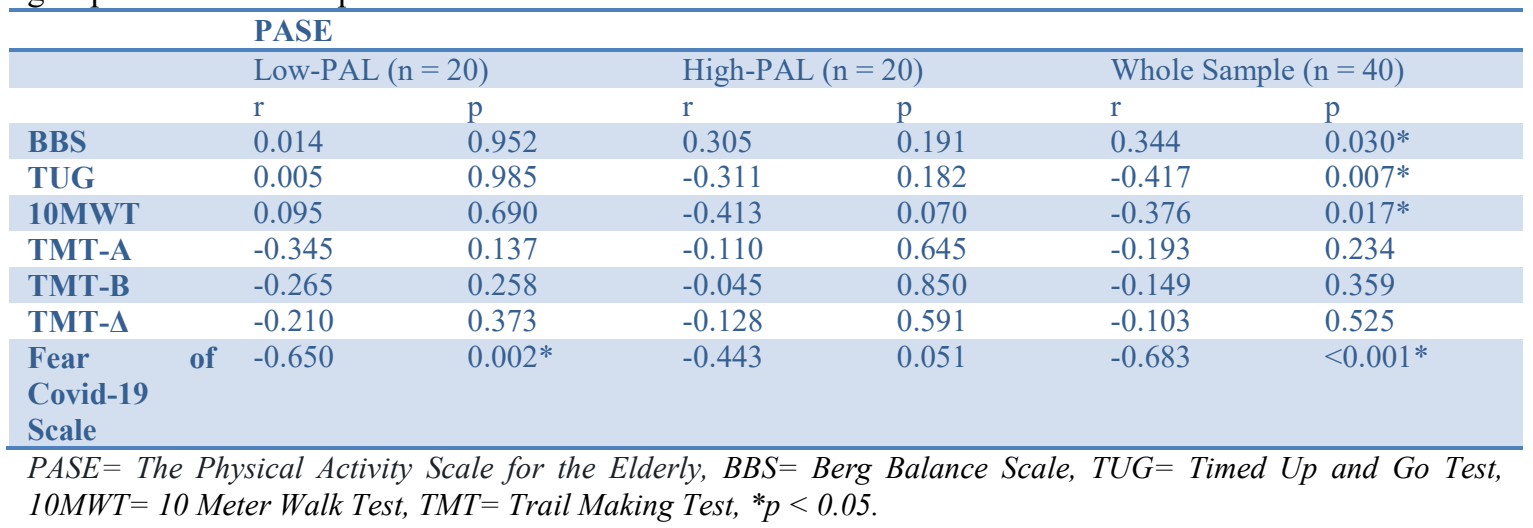

\section{Discussion}

Our study has aimed to compare the balance, gait, cognitive functions and fear of Covid-19 in older adults according to PALs and investigate the relationship between PALs and balance, gait, cognitive functions and fear of Covid-19 of older adults in times of Covid-19 pandemic. Overall, the results showed that the fear of Covid-19 was most different parameter in two groups. Besides, there is no difference in terms of executive functions. Also, there is no relationship between PALs and other parameters except fear of Covid-19 in older adults who have low PALs. To the best of our knowledge, no study has focused on PALs and differences in physical, cognitive and mental performances between physically active and inactive older adults and relationship between PALs and physical, cognitive and mental performances in times of Covid-19. Therefore, this study is first study that focused on this subject.

There are no objective data on the effect of public health countermeasures against Covid19 on the PALs of older adults. However, in a study conducted by Suzuki et al. (2020) on Japanese older adults, the majority of the participants subjectively reported that their PALs have decreased during the Covid-19 pandemic (13). When we compared our PASE scores with other studies in Turkish older adults before the Covid-19 pandemic $(16,17)$, it can be speculated that there is a drastic decrease in terms of PALs. Outdoor time is strongly associated with physical activity for older adults (23) and it is severely restricted since most of the outdoor activity places (parks, community centers, cafes etc.) were closed during the pandemic and a lockdown was imposed for older adults. Thus, such decrease in PALs could be predictible and accounted for decreased outdoor time of older adults.

Dawe et al. (2018) showed that balance deficits are associated with physical inactivity in older people (7). Moreover, Buatois et al. (2007) observed that current physical activity in older adults is a major determinant factor of balance control and even recently started physical activity habit produces better postural control (24). We have not come across any studies investigating the effects of recently quitted physical activity habits on the balance of older adults, yet it can be suggested that these effects of physical activity could be the opposite. Considering the time our study was conducted, Covid-19 countermeasures were affecting our sample for nearly one year. Thus, even if the participants in the Low-PAL group had high physical activity level before the pandemic, they may still suffer from the 
negative effects of low physical activity on balance.

Dawe et al. (2018) also showed that gait problems are associated with total PALs in older adults (7). Cromwell and Newton (2004) stated that there is a relationship between impaired balance and impaired gait in healthy older adults (25). Hence, low PALs may have similar effects with balance on gait in older adults during the Covid-19 pandemic.

There is evidence that PALs in older adults are associated with cognitive functions [9]. Bixby el al. (2007) showed that habitual physical activity is positively related to cognitive performance in older adults (26). Our results seem conflicting with those in the literature. However, these results considered habitual physical activity in older adults. The Covid-19 countermeasures, lockdowns and imposed social isolations have considerably changed the habits of older adults. Additionally, Zhu et al. (2017) stated that moderate-to-vigorous physical activity is associated with cognitive functions in older adults not with light-intensity physical activity (27). Therefore, it should be taken into account that there is a shortage of facilities for doing moderate-to-vigorous physical activity because of the pandemic. Moreover, Bourassa et al. (2017) showed that the effect of social participation on cognitive functioning is comparable to physical activity level in older adults (28). The Covid-19 countermeasures affected the social participation of older adults also. Thus, these factors may explain the difference in our results regarding cognitive function.

\section{REFERENCES}

1. Zhu N, Zhang D, Wang W, et al. A Novel Coronavirus from Patients with Pneumonia in China, 2019. N Engl J Med. 2020;382:727-33.

2. García-Fernández L, Romero-Ferreiro V, López-Roldán PD, et al. Mental Health in Elderly Spanish People in Times of COVID19 Outbreak. Am $J$ Geriatr Psychiatry. 2020;28:1040-45.

3. Ustun G. Determining depression and related factors in a society affected by COVID-19 pandemic. Int $J$ Soc Psychiatry. 2020;30:20764020938807.

4. Argan M, Pakiş Ş, Kesim Ü, et al. Flow in Home-Based Leisure During the COVID-19 Lockdown: A Case Study for People Aged 65
Alsalhe et al. (2020) showed that there is a negative relationship between the PALs and the fear of Covid-19 (10). Hence, it can be expected that older adults who have lower PALs have more fear related to Covid-19. We found similar relationship in total sample. Hence, our results are in line with those in the literature. Also, in our study we found that the PALs affected fear of Covid-19 much higher than other parameters.

It should be noted that the present study has some limitations. First, we did not have any knowledge about the PALs of the participants before the Covid-19 pandemic. Thus, the effects of these parameters on our results remain unclear. Second, the progression of pandemic and the countermeasures vary from country to country and time to time. Consequently, this may limit the generalization of the results.

\section{Conclusions}

Our results are in line with the results of previous studies before the Covid-19 pandemic in terms of physical functions. However, current theories about the relationship between cognitive functions and PALs of older adults may not be appropriate during the Covid-19 pandemic. Therefore, we recommend that future studies address the effect of imposed, not voluntary, inactivity on the cognitive functions of older adults.

Bu araştırmanın Türkçe özeti, 8-10 Nisan 2021 tarihlerinde Burdur, Türkiye'de düzenlenmiş olan 4. Uluslararası Sağlı Bilimleri ve Yaşam Kongresinde sözel bildiri olarak sunulmuştur.

and Over in Turkey. Int J Environ Res Public Health. 2020;4:5-17.

5. Wong $\mathrm{CH}$, Wong SF, Pang WS, et al. Habitual walking and its correlation to better physical function: implications for prevention of physical disability in older persons. J Gerontol A Biol Sci Med Sci. 2003;58:555-60.

6. Lautenschlager NT, Almeida OP, Flicker L, et al. Can physical activity improve the mental health of older adults? Ann Gen Hosp Psychiatry. 2004;3:12.

7. Dawe RJ, Leurgans SE, Yang $J$, et al Association Between Quantitative Gait and Balance Measures and Total Daily Physical Activity in Community-Dwelling Older 
Adults. J Gerontol A Biol Sci Med Sci. 2018;73:636-42.

8. Ciprandi D, Bertozzi F, Zago M, et al. Study of the association between gait variability and physical activity. Eur Rev Aging Phys Act. 2017;14:19.

9. Scherder EJ, Van Paasschen J, Deijen JB, et al. Physical activity and executive functions in the elderly with mild cognitive impairment. Aging Ment Health. 2005;9:272-80.

10. Alsalhe TA, Aljaloud SO, Chalghaf N, et al. Moderation Effect of Physical Activity on the Relationship Between Fear of COVID-19 and General Distress: A Pilot Case Study in Arabic Countries. Front Psychol. 2020;11:570085.

11. Holwerda TJ, Beekman AT, Deeg DJ, et al. Increased risk of mortality associated with social isolation in older men: only when feeling lonely? Results from the Amsterdam Study of the Elderly (AMSTEL). Psychol Med. 2012;42:843-53.

12. Banerjee D. The impact of Covid-19 pandemic on elderly mental health. Int $J$ Geriatr Psychiatry. 2020;35:1466-67.

13. Suzuki Y, Maeda N, Hirado D, et al. Physical Activity Changes and Its Risk Factors among Community-Dwelling Japanese Older Adults during the COVID-19 Epidemic: Associations with Subjective Well-Being and HealthRelated Quality of Life. Int $J$ Environ Res Public Health. 2020;17:6591.

14. World Health Organization. Global recommendations on physical activity for health [online]. [Available at https://www.who.int/publications/i/item/97892 41599979] [Accessed 08 March 2021].

15. Hammami A, Harrabi B, Mohr M, et al. Physical activity and coronavirus disease 2019 (COVID-19): specific recommendations for home-based physical training. Managing Sport and Leisure. 2020;1-6.

16. Duray M, Genç A. The relationship between physical fitness and falling risk and fear of falling in community-dwelling elderly people with different physical activity levels. Turk $J$ Med Sci. 2017;47:455-62.

17. Ayvat E, Kilinç M, Kirdi N. The Turkish version of the Physical Activity Scale for the Elderly (PASE): its cultural adaptation, validation, and reliability. Turk $J$ Med Sci. 2017;47:908-15.

18. Sahin F, Yilmaz F, Ozmaden A, et al. Reliability and validity of the Turkish version of the Berg Balance Scale. J Geriatr Phys Ther. 2008;31:32-7.

19. Podsiadlo D, Richardson S. The timed "Up \& Go": a test of basic functional mobility for frail elderly persons. $J$ Am Geriatr Soc. 1991;39:142-8.

20. Lang JT, Kassan TO, Devaney LL, et al. TestRetest Reliability and Minimal Detectable Change for the 10-Meter Walk Test in Older Adults With Parkinson's disease. $J$ Geriatr Phys Ther. 2016;39:165-70.
21. Voos MC, Custódio EB, Malaquias J Jr. Relationship of executive function and educational status with functional balance in older adults. J Geriatr Phys Ther. 2011;34:118.

22. Haktanir A, Seki T, Dilmaç B. Adaptation and evaluation of Turkish version of the fear of COVID-19 Scale. Death Stud. 2020:1-9.

23. Harada K, Lee S, Lee S, et al. Objectivelymeasured outdoor time and physical and psychological function among older adults. Arch Gerontol Geriatr. 2017;17:1455-62.

24. Buatois S, Gauchard GC, Aubry C, Benetos A, Perrin P. Current physical activity improves balance control during sensory conflicting conditions in older adults. Int J Sports Med. 2007;28:53-8.

25. Cromwell RL, Newton RA. Relationship between balance and gait stability in healthy older adults. J Aging Phys Act. 2004;12:90100.

26. Bixby WR, Spalding TW, Haufler AJ, et al. The unique relation of physical activity to executive function in older men and women. Med Sci Sports Exerc. 2007;39:1408-16.

27. Zhu W, Wadley VG, Howard VJ, et al. Objectively Measured Physical Activity and Cognitive Function in Older Adults. Med Sci Sports Exerc. 2017;49:47-53.

28. Bourassa KJ, Memel M, Woolverton C, et al. Social participation predicts cognitive functioning in aging adults over time: comparisons with physical health, depression, and physical activity. Aging Ment Health 2017;21:133-46. 